\title{
Polygalacturonase Isozymes Produced by Phomopsis cucurbitae in Relation to Postharvest Decay of Cantaloupe Fruit
}

\author{
Jiuxu Zhang, Benny D. Bruton, and Charles L. Biles
}

First and second authors: USDA-ARS, South Central Agricultural Research Laboratory, Lane, OK 74555; and third author: Department of Biology, East Central University, Ada, OK 74820.

Accepted for publication 30 June 1997.

\begin{abstract}
Zhang, J. X., Bruton, B. D., and Biles, C. L. 1997. Polygalacturonase isozymes produced by Phomopsis cucurbitae in relation to postharvest decay of cantaloupe fruit. Phytopathology 87:1020-1025.

Production of polygalacturonase (PG), a cell wall-degrading enzyme, by Phomopsis cucurbitae (latent infection fungus) was studied in relation to different carbon sources and various stages of cantaloupe fruit development. P. cucurbitae produced multiple PG isozymes both in vitro and in vivo. The fungus produced the highest PG activity and the greatest number of isozymes on pectin compared with those produced on glucose, galactose, and sucrose. Eight P. cucurbitae PG isozymes (pIs 3.7, 4.2, $6.6,7.0,7.3,7.5,7.8$, and 8.6) were detected in extract from inoculated mature fruit ( 40 days after anthesis) by isoelectric focusing. Isozyme bands with pIs of $4.2,7.3$, and 7.8 were the most prominent. A similar set
\end{abstract}

ABSTRACT of PG isozymes was produced by $P$. cucurbitae in autoclaved mature fruit tissue (mesocarp). When tissue discs taken from 20-, 30-, 40-, and 50day postanthesis fruit were inoculated with $P$. cucurbitae, PG activity and the number of PG isozymes extracted from the macerated fruit tissue discs increased with the degree of fruit maturity and ripening. Increases in PG activity and PG isozymes were also correlated with reactivation of latent infections and the beginning of tissue maceration. An anionic PG isozyme (pI 4.2) was only visualized on decayed 50-day-old fruit exocarp, as well as 40- and 50-day-old fruit mesocarp. The experimental results support the hypotheses that $P$. cucurbitae PG isozymes play an important role in fruit decay once latent infection becomes active following harvest.

Additional keywords: catabolite repression, fruit rot.

We have reported, in abstract form, that $P$. cucurbitae produces several PG isozymes in vitro and in vivo $(42,43)$. As a further step in understanding the role of $P$. cucurbitae PG in the fruit decay process and its relation to latent infection, the current study sought to determine (i) the effect of carbon source on the production of PG isozymes; (ii) the PG isozymes produced in autoclaved fruit tissues and fresh fruit tissue; and (iii) PG activity and expression of PG isozymes in relation to the decay of exocarp or mesocarp tissue at various stages of fruit development through postharvest storage.

\section{MATERIALS AND METHODS}

Fungal culture. A P. cucurbitae isolate, Pc-1062, was isolated from decayed cantaloupe fruit produced at the Lane Research Station, USDA-ARS, Lane, OK. The isolate was grown on potato dextrose agar (PDA) at $25^{\circ} \mathrm{C}$ for 4 days and then transferred to autoclaved soil tubes. The fungus was allowed to grow for another 7 days in the soil tubes, and then stored at $4{ }^{\circ} \mathrm{C}$. The isolate, recovered as needed from storage, was grown on PDA at $25^{\circ} \mathrm{C}$ for 4 days prior to inoculation of fruit tissues. All experiments were conducted at $25^{\circ} \mathrm{C}$.

Production of PG by $P$. cucurbitae on different carbon sources. Modified Richard's solution containing $10 \mathrm{~g}$ of $\mathrm{KNO}_{3}, 5$ $\mathrm{g}$ of $\mathrm{KH}_{2} \mathrm{PO}_{4}, 2.5 \mathrm{~g}$ of $\mathrm{MgSO}_{4} \cdot 7 \mathrm{H}_{2} \mathrm{O}, 0.02 \mathrm{~g}$ of $\mathrm{FeCl}_{3} \cdot \mathrm{H}_{2} \mathrm{O}, 1,000$ $\mathrm{ml}$ of distilled water, and different carbon sources was used to culture the fungus. Carbon sources were $1 \%(\mathrm{wt} / \mathrm{vol})$ pectin, sucrose, glucose, galactose, or $0.1 \%(\mathrm{wt} / \mathrm{vol}$ ) lyophilized fruit tissue (mesocarp). Two 7-mm plugs of $P$. cucurbitae from PDA culture were introduced into each $250-\mathrm{ml}$ flask containing $150 \mathrm{ml}$ of autoclaved or filter-sterilized medium. The flasks were placed on an orbital shaker (115 rpm) for 8 days, and the contents of the flasks were filtered through Miracloth (Calbiochem-Behring, La Jolla, CA). Filtrates were centrifuged at $20,000 \times g$ for $20 \mathrm{~min}$. The supernatants were separated from other contents of the filtrate and stored at
Publication no. P-1997-0731-03R

This article is in the public domain and not copyrightable. It may be freely reprinted with customary crediting of the source. The American Phytopathological Society, 1997.
Corresponding author: B. D. Bruton; E-mail address: bbruton-usda@lane-ag.org

Mention of a trademark, proprietary product, or vendor does not constitute a guarantee or warranty of the product by the USDA and does not imply its approval to the exclusion of other products of vendors that may also be suitable. 
$-20^{\circ} \mathrm{C}$. The dry weight of the fungal mass left on the Miracloth and in the filtrate was determined after being dried at $60^{\circ} \mathrm{C}$ for 7 days.

Fruit inoculation. Full-slip cantaloupe fruit (cv. Magnum 45) were collected from field plots at the Lane Research Station and stored at $4^{\circ} \mathrm{C}$ for 10 days (50 days postanthesis) before inoculation. Fruit were surface-disinfested with $80 \%$ ethanol, and tissue samples were removed with a cork borer (7-mm diameter). A PDA fungal plug (5-mm diameter) of P. cucurbitae was placed into each of five inoculation sites per fruit. An autoclaved cotton ball was placed behind the inoculum, the hole sealed with Kwik Seal caulk (DAP Inc., Dayton, $\mathrm{OH}$ ), and the fruit incubated at $25^{\circ} \mathrm{C}$. After 5 days, the lesions from each of 20 fruit were cut perpendicularly, and the diameter of macerated tissues was recorded. Decayed tissues were collected and stored at $-20^{\circ} \mathrm{C}$.

Inoculation of fruit tissue discs. Cantaloupe fruit (cv. Magnum 45) were harvested at 20,30, 40 (horticultural maturity), and 50 days $\left(10\right.$ days postharvest stored at $\left.4^{\circ} \mathrm{C}\right)$ postanthesis, respectively, from plants grown in the greenhouse. Tissue plugs $(18-\mathrm{mm}$ diameter) were removed from surface-disinfested fruit with a cork borer. The epidermis was removed and discarded. The remaining plug was sliced into exocarp (2-mm thick) and outer mesocarp (10-mm thick). Six discs of each tissue type were transferred into each of three autoclaved glass plates containing moist filter paper. Each disc was positioned such that the exterior part was exposed. Hyphal discs (5-mm diameter) of $P$. cucurbitae were taken from the leading edge of the fungal colony and placed onto the surface of each fruit tissue disc. After $72 \mathrm{~h}$, the edge of macerated tissue was determined using a dissecting probe. The macerated tissue was soft, water-soaked, and slightly discolored, whereas healthy tissue remained firm and natural looking. The diameter of macerated tissue was measured, and the decayed tissues were collected and stored at $-20^{\circ} \mathrm{C}$.

Protein extraction from fruit tissues. Ten grams of decayed tissues, sampled from inoculated fruit or fruit tissue discs, was placed in $10 \mathrm{ml}$ of an extracting buffer containing $50 \mathrm{mM} \mathrm{Na}$ acetate, $500 \mathrm{mM} \mathrm{NaCl}$, and $1 \mathrm{mM}$ EDTA (pH 5.0) in a centrifuge tube. The mixture was homogenized for $1 \mathrm{~min}$ using a polytron (Kinematica, Littau, Switzerland). The homogenates were centrifuged at $32,000 \times g$ for $20 \mathrm{~min}$, and supernatants were collected. Healthy tissues processed by the same procedure served as controls.

PG and protein assays. PG activity of the samples from shake cultures, inoculated fruit, or tissue discs were assayed by measuring reducing groups. The 2-cyanoacetamide method as described by Gross (22) was utilized, with galacturonic acid as a standard. One unit of enzyme activity was defined as $1 \mu \mathrm{mol}$ of reducing groups released per minute at $30^{\circ} \mathrm{C}$. Protein was determined using a protein assay kit (Bio-Rad Laboratories, Hercules, CA) according to the manufacturer, using bovine serum albumin as a standard.

Detection of PG isozymes. Isoelectric focusing-polyacrylamide gel electrophoresis (IEF-PAGE) was used to separate and visualize $P$. cucurbitae PG isozymes. IEF gels (total acrylamide concentration $=7 \%$; and degree of cross-linking $=3 \%, 0.5$-mm thickness) containing 5\% (vol/vol) 40\% ampholytes (pH 3.5 to 10) (Pharmacia LKB Biotechnology Inc., Piscataway, NJ) were cast using an IEF kit (Pharmacia LKB Biotechnology Inc.). Samples prepared from shake cultures, inoculated fruit, or inoculated fruit tissue discs were dialyzed against distilled water and concentrated 10-fold using a Centriprep concentrator (Amicon, Beverly, MA) with a 10,000molecular weight cut-off membrane before loading onto IEF gels. Samples $(20 \mu \mathrm{l} /$ replication) were applied, and gels were run on the Multiphor II apparatus (Pharmacia LKB Biotechnology Inc.) at a power of $20 \mathrm{~W}$ and a maximum of $2,000 \mathrm{~V}$ for $2 \mathrm{~h}$, including 20 min of pre-IEF. PG isozymes were detected by overlaying the running gel with a pectate agarose gel containing $1 \%$ agarose and $0.1 \%$ polygalacturonic acid in $0.1 \mathrm{M} \mathrm{Na}$-acetate buffer, $\mathrm{pH}$ 5.0. Incubation and staining procedures were conducted according to Ried and Collmer (35). The pIs of the respective PG isozymes were calculated by running the proteins from a pI calibration kit (pI 310) (Pharmacia LKB Biotechnology Inc.) on the same gels as the samples and staining them with Coomassie Blue R-350 (Pharmacia LKB Biotechnology Inc.).

Analysis of data. Each experiment was repeated at least once, and all experiments had three or more replicates per treatment. Analysis of variance of data was performed by a general linear model procedure using SAS (SAS Institute, Cary, NC). Treatment means were compared using Duncan's multiple range test $(P=0.05)$.

\section{RESULTS}

Fruit decay. $P$. cucurbitae isolate Pc-1062 produced mean lesion diameters of $6.1 \mathrm{~cm}$ after 5 days at $25^{\circ} \mathrm{C}$. The lesions were soft, water-soaked, symmetrical, easily distinguishable from healthy tissues, and the same as those caused by natural infections.

Effects of carbon source on fungal growth, PG activity, and isozymes produced by $\boldsymbol{P}$. cucurbitae. The specific carbon source used affected the total PG activity and isozymes produced by $P$. cucurbitae in shake culture (Figs. 1 and 2). The highest PG activity was obtained when pectin was used as the carbon source, followed by sucrose, fruit mesocarp, glucose, and galactose. There was similar fungal growth on each of the other carbon sources, with the greatest growth produced on mesocarp (Fig. 3). Total PG activity produced by $P$. cucurbitae on different carbon sources did not correlate with fungal growth on the same sources (Figs. 1 and 3).

The number of PG isozymes produced on glucose, galactose, and sucrose was less than that produced on pectin (Fig. 2). P. cucurbitae, utilizing pectin, produced at least $15 \mathrm{PG}$ isozymes with a pI range of 3.7 to 8.6. When the simple sugars, glucose, galactose, and sucrose, were used as the sole carbon sources, seven PG isozymes (pIs 4.0, 4.2, 4.5, 7.3, 7.5, 7.8, and 8.6) were detected on glucose and sucrose, and five PG isozymes (pIs 4.0, 4.2, 7.5, 7.8, and 8.6) were detected on galactose. When autoclaved fruit tissue (mesocarp) was used as the carbon source in the shake culture, 10 PG isozymes (pIs 3.7, 4.2, 4.3, 6.6, 7.0, 7.3, 7.5, 7.8, 8.2, and 8.6) were visualized (Fig. 4).

PG isozymes produced by $P$. cucurbitae in inoculated fruit. Eight PG isozymes with pIs of 3.7, 4.2, 6.6, 7.0, 7.3, 7.5, 7.8, and

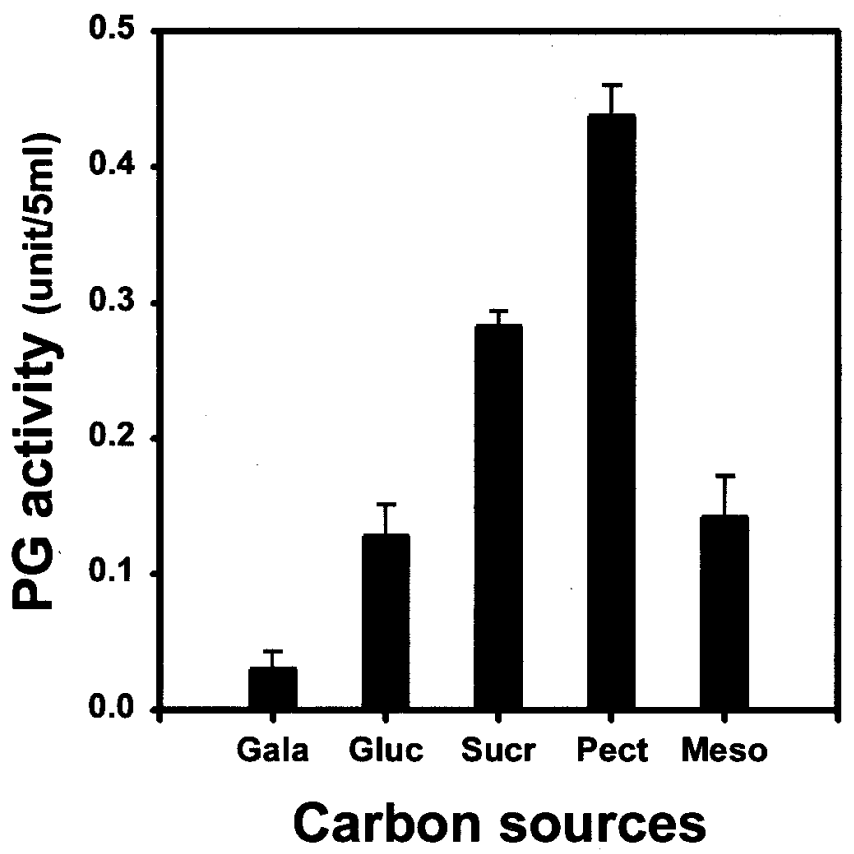

Fig. 1. Polygalacturonase activity of Phomopsis cucurbitae isolate Pc-1062 grown for 8 days in shake culture with galactose, glucose, sucrose, and pectin, respectively, as the sole carbon source. Bars indicate standard errors of four replicates. 


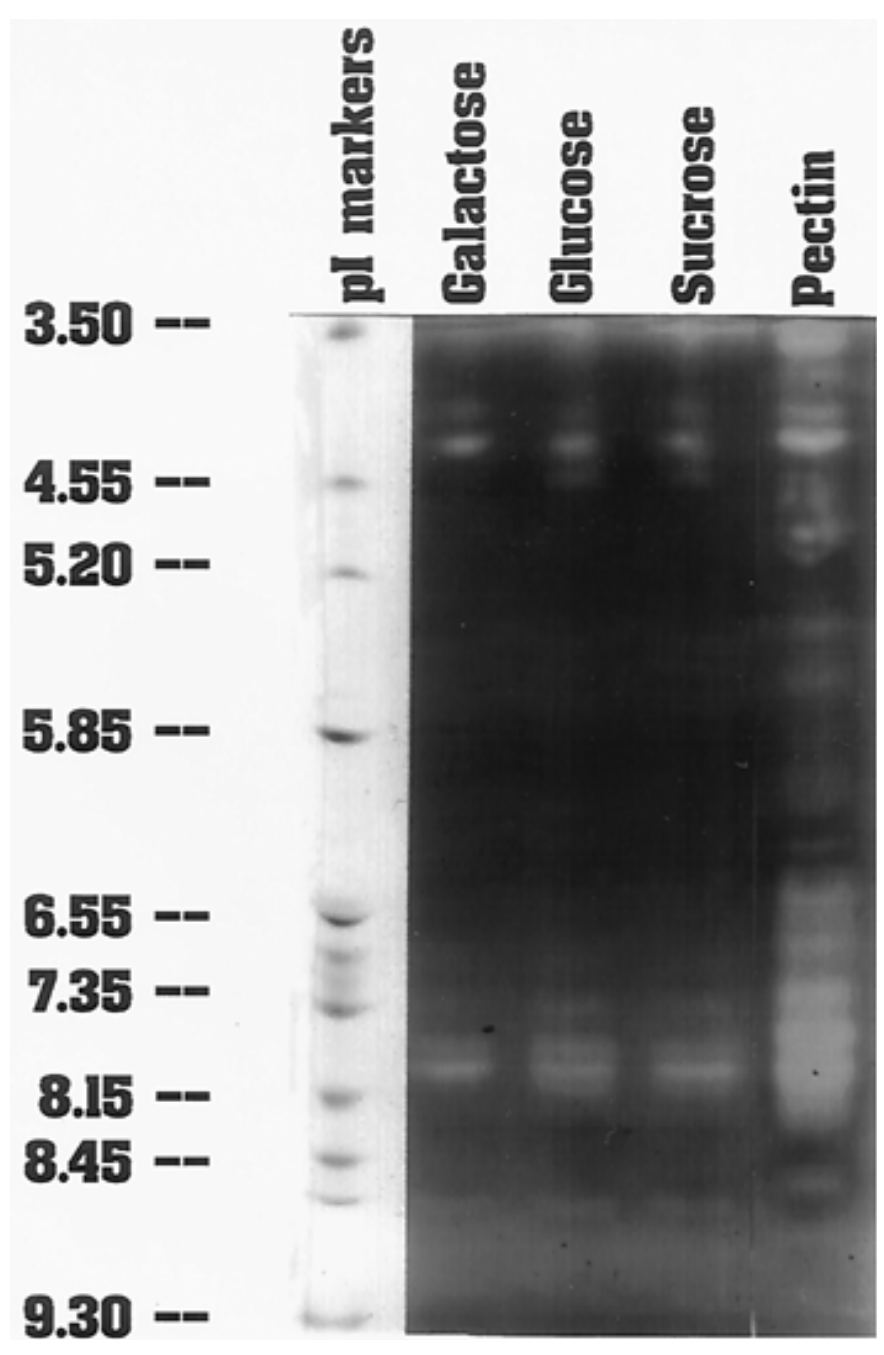

Fig. 2. Isoelectric focusing-polyacrylamide gel electrophoresis of polygalacturonase isozymes produced by Phomopsis cucurbitae isolate Pc-1062 in 8-day shake culture using different carbon sources. pI markers are illustrated on the left.

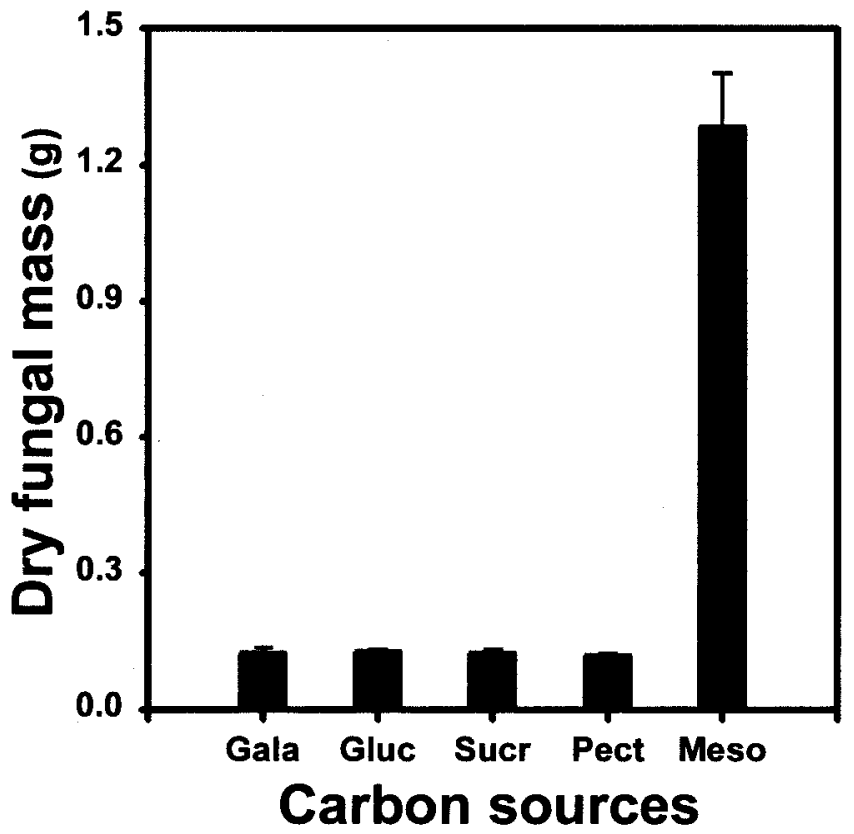

Fig. 3. Growth of Phomopsis cucurbitae isolate Pc-1062 in 8-day shake cultures using galactose, glucose, sucrose, and pectin, respectively, as the sole carbon source. Bars indicate standard errors of four replicates.
8.6 were detected in decayed mature fruit tissue (mesocarp) 6 days after inoculation at $25^{\circ} \mathrm{C}$ (Fig. 4). PG isozymes with pIs of 4.2, 7.3, and 7.8 were consistently detected as intense bands on IEF gels. $P$. cucurbitae produced a set of PG isozymes in autoclaved fruit tissue similar to those in inoculated fruit (Fig. 4). There was no PG activity detected in extracts from healthy fruit tissues.

Effects of fruit development stages and tissue types on $\boldsymbol{P}$. cucurbitae PG activity, isozymes, and fruit tissue maceration. Total specific PG activity of P. cucurbitae in inoculated fruit tissue discs increased as the fruit reached maturity (Fig. 5). Three days after inoculation, specific PG activity on 20- and 30-day-old fruit tissue discs was significantly lower $(P=0.05)$ than that on 40- (horticultural maturity) and 50-day-old tissue discs. There was no difference $(P=0.05)$ in PG activity between 20 - and 30-dayold, or 40- and 50-day-old fruit exocarp. For fruit mesocarp, PG activity on 20- and 30-day-old fruit tissue discs was lower $(P=$ 0.05 ) than on 40- and 50-day-old tissue discs, and PG activity on 50-day-old tissue discs was higher $(P=0.05)$ than on 40 -day-old tissue discs (Fig. 5). There was no difference $(P=0.05)$ in PG activity between mesocarp and exocarp discs at the same stages of fruit development. PG activity was not detected from noninoculated fruit tissue discs taken from the fruit at the same developmental stages.

Maceration of fruit tissue discs increased as the fruit ripened (Fig. 6). Maceration of 40- or 50-day-old fruit mesocarp discs

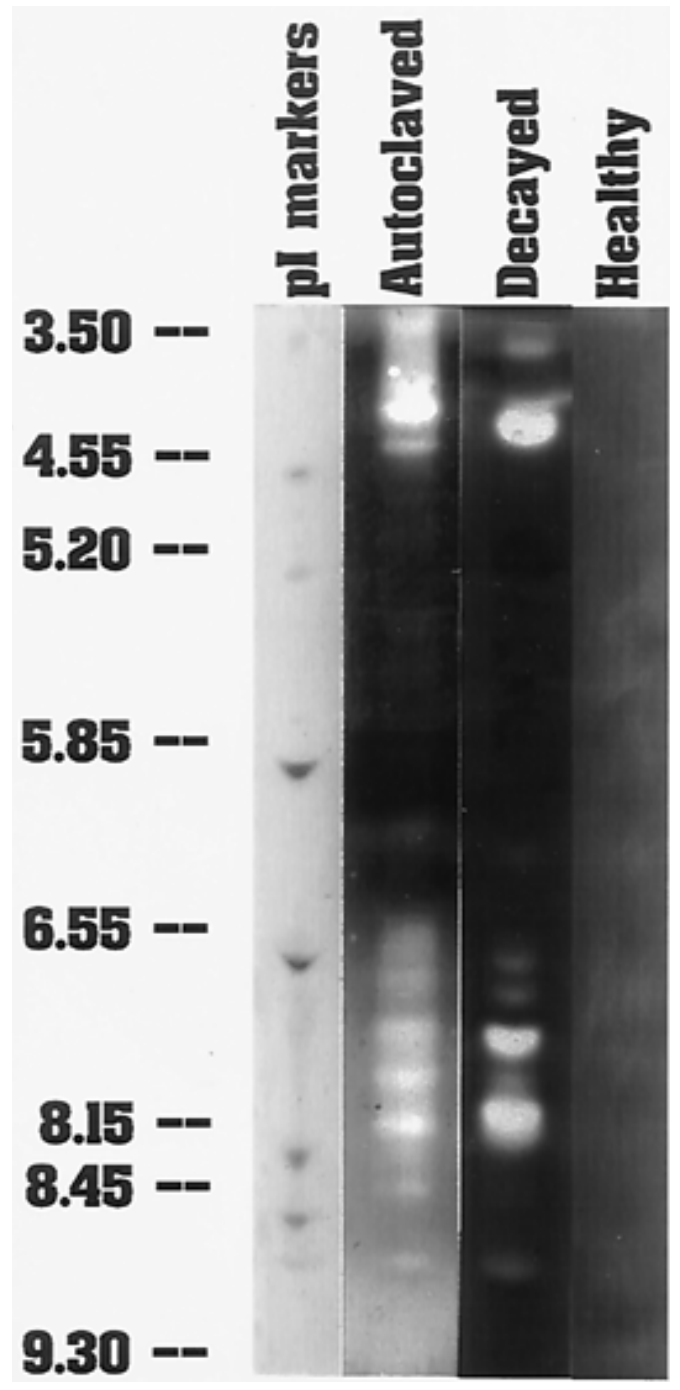

Fig. 4. Isoelectric focusing-polyacrylamide gel electrophoresis of polygalacturonase isozymes produced by Phomopsis cucurbitae isolate Pc-1062 in autoclaved cantaloupe fruit tissue, decayed tissue, and noninoculated tissue. pI markers are illustrated on the left. 
was 66 and 34\% greater when compared with 20- and 30-day-old fruit mesocarp discs, respectively. When fruit exocarp discs were inoculated with $P$. cucurbitae, maceration of 40- or 50-day-old fruit tissue discs increased 70 and $22 \%$ over that observed on 20- and 30day-old fruit discs, respectively. There was no difference $(P=0.05)$ in tissue maceration between 40- and 50-day-old fruit tissue discs.

The number of PG isozymes produced by $P$. cucurbitae in both exocarp and mesocarp discs increased as the fruit age increased (Fig. 7). However, as the fruit matured, the number of expressed PG isozymes increased and their pIs decreased. An anionic PG isozyme (pI 4.2) was only visualized from decayed discs of 50-day-old fruit exocarp and the mesocarp of 40- to 50-day-old fruit (Fig. 7).

\section{DISCUSSION}

P. cucurbitae is a latent infection pathogen that is activated upon fruit ripening. The triggering mechanisms by which the fungus again becomes active are largely unknown. However, the ability of $P$. cucurbitae to macerate tissue corresponded to the accumulation of PG isozymes in mature fruit (40 to 50 days postanthesis). Eight PG isozymes were detected from decayed cantaloupe fruit tissue following inoculation with $P$. cucurbitae. The same set of PG isozymes was found from fruit naturally infected with $P$. $\mathrm{cu}$ curbitae (data not shown). PG activity was not detected from healthy cantaloupe fruit at any developmental stage, which is consistent with other reports $(8,23,28,30)$. The PG isozymes detected from decayed cantaloupe fruit tissues were, therefore, considered to be of fungal origin.

Accumulation of PG varied depending on carbon source, and confirmed that PG production by $P$. cucurbitae is not constitutive, but is dependent on ripening-related signals. Galactose, glucose, and sucrose suppressed, or failed to induce, total $P$. cucurbitae PG activity and the accumulation of specific PG isozymes when compared with pectin in shake culture, autoclaved fruit tissue, and fresh fruit tissue. Galactose was the strongest suppressor of $P$. cucurbitae PG activity and isozyme accumulation. Galactose and other monosaccharides have been shown to catabolically repress PG activity in many microorganisms $(2,6,7,17,20,21,24,29,33)$.

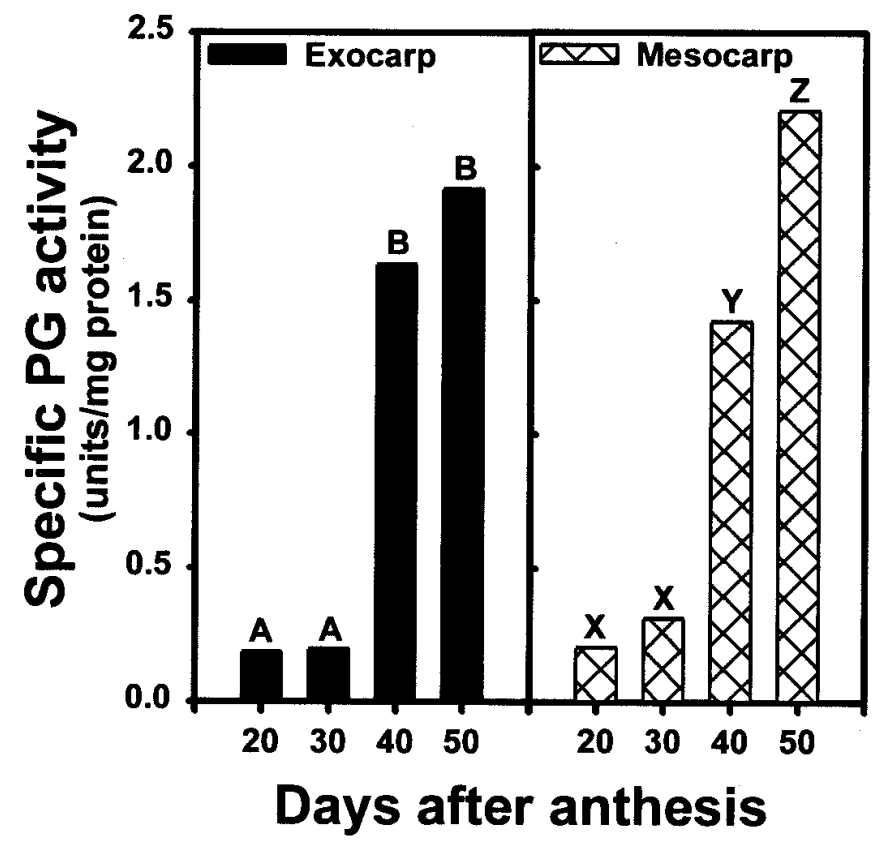

Fig. 5. Polygalacturonase activity of Phomopsis cucurbitae isolate Pc-1062 on different fruit tissue discs taken from cantaloupe fruit at different developmental stages. Means with the same letter on each bar, for each tissue type, are not significantly different $(P=0.05)$ according to Duncan's multiple range test.
The ability of $P$. cucurbitae to grow on a carbon source was not directly related to PG activity. Growth of $P$. cucurbitae on pectin, sucrose, glucose, and galactose was similar. When ripe fruit tissue (autoclaved mesocarp) was used as the carbon source, greater fungal growth was observed than on any of the single carbon sources. However, P. cucurbitae grown on sucrose and pectin produced higher PG activity when compared with mesocarp. When hyphal mass, total PG production, and specific PG isozymes are com-

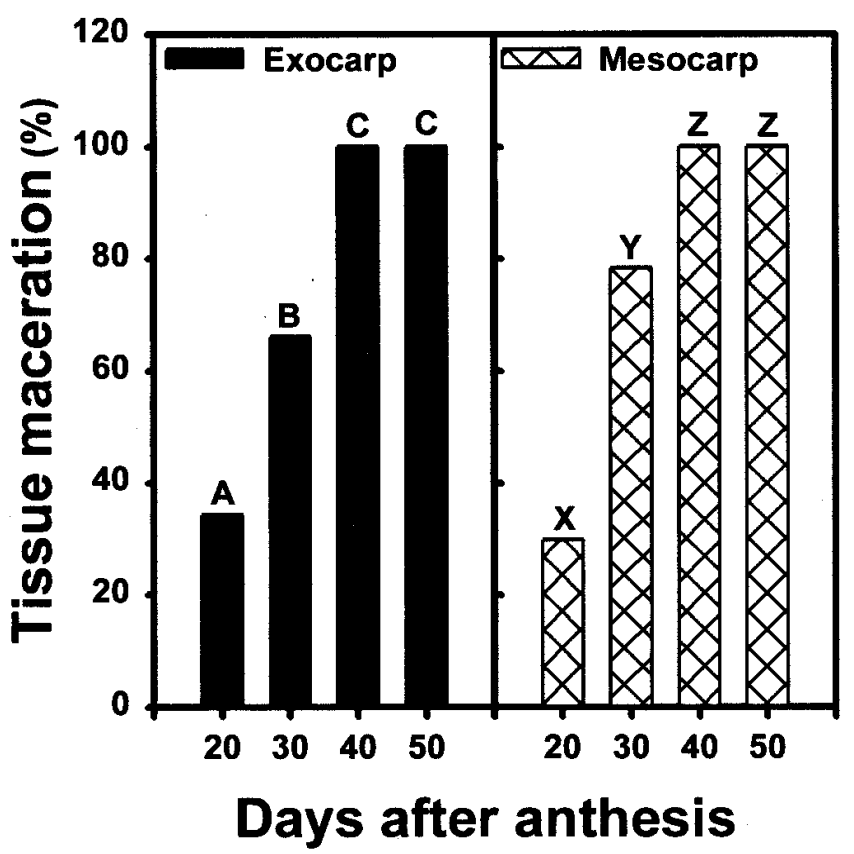

Fig. 6. Percentage of maceration of fruit tissue discs from different ages of cantaloupe fruit by Phomopsis cucurbitae isolate Pc-1062. Means with the same letter on each bar, for each tissue type, are not significantly different $(P$ $=0.05$ ) according to Duncan's multiple range test.

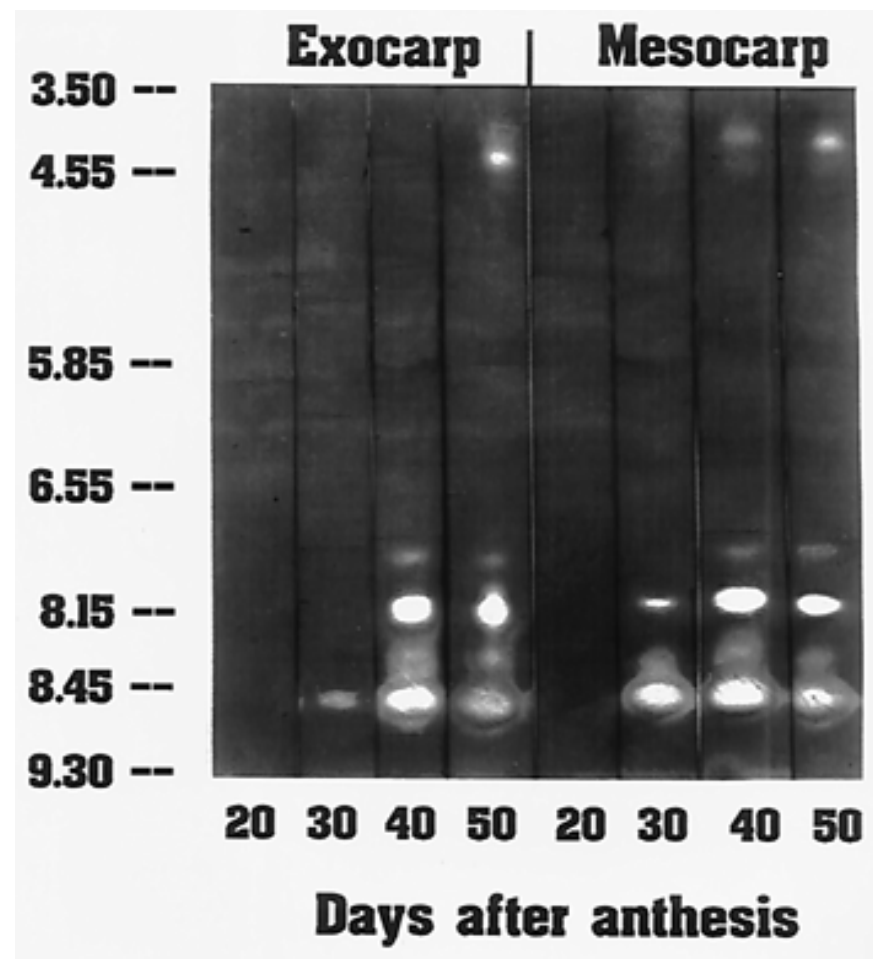

Fig. 7. Polygalacturonase isozymes produced by Phomopsis cucurbitae isolate Pc-1062 on cantaloupe fruit tissue discs at different developmental stages. pI markers are illustrated on the left. 
pared, it is apparent that enhanced growth does not correspond with enhanced PG production.

As in the current study, differences in PG isozymes produced by fungal pathogens in vitro and in vivo have been previously demonstrated $(4,36,41)$. Botrytis cinerea produced five PG isozymes in shake culture using pectin as the carbon source, but produced only one in decaying apple fruit $(38,39)$. In our study, there were at least 15 P. cucurbitae PG isozymes detected from shake culture with pectin as the carbon source, but only eight isozymes were detected from $P$. cucurbitae-inoculated mature fruit tissue. Autoclaved fruit tissue used as a carbon source for $P$. cucurbitae yielded 10 PG isozymes, having similar pIs to those produced in inoculated fruit. In immature fruit inoculated with $P$. cucurbitae, low levels of PG activity and very few isozymes were detected. The in vivo experiments confirmed that the fungus produces a group of PG isozymes that coincide with the reactivation of infection. Metabolic shifts that occur from immature to ripe fruit appear to induce these specific PG isozymes. Multiple forms of PG may be derived from different genes or from a single gene product that undergoes differential glycosylation $(11,12,18)$. The genetic basis of PG isozyme production by $P$. cucurbitae is currently unknown.

In many immature fruit, the mechanisms limiting pathogen aggression are associated with either preformed antimicrobial substances or with phytoalexins, enzymes, or physical resistance structures (25). In the current study, when the fruit tissue discs representing different age cantaloupe fruit were inoculated with $P$. cucurbitae, immature fruit (20 and 30 days old) exhibited a much lower percentage of maceration compared with mature fruit (40 and 50 days old). This suggests that the immature fruit have biochemical or physical factors that restrict fungal growth or production of the cell wall-degrading enzymes by the fungus. These inhibiting factors may contribute to the fungal dormancy during the early stages of fruit development and become ineffective at fruit maturity.

In addition, $P$. cucurbitae produced significantly lower PG activity on immature fruit tissues (20 and 30 days old) than on mature fruit tissues (40 and 50 days old). Bruton et al. (10) used a partially purified PG preparation (a mixture of different isozymes) from decayed cantaloupe fruit to macerate fruit tissues harvested at 20,30, 40, and 50 days postanthesis. They observed that little tissue maceration occurred on 20-, 30-, and 40-day-old fruit tissues compared with the 50-day-old fruit tissues, suggesting a plant metabolic PG inhibitor present in the younger fruit tissues. Pathogen PG-inhibiting proteins (PGIP) have been demonstrated from several plant species, and some of them have been purified and characterized $(1,13,19,26,40)$. Johnston et al. (26) purified a PGIP from immature raspberry fruit that inhibited endo-PGs from $B$. cinerea. They found that the activity of the PGIP was greatest in immature green fruit, and its activity decreased substantially during ripening. This decline was inversely correlated with the pathogen's ability to colonize the fruit (26). Information in the current study suggests that immature cantaloupe fruit may have a higher concentration of PG-inhibitor(s) compared with postharvest fruit. The dynamics of the PG-inhibitor(s) during fruit ripening may also be involved in the regulation of $P$. cucurbitae latent infection. Purifying and characterizing the major $P$. cucurbitae PG isozymes from infected fruit and PG inhibitors from the immature cantaloupe fruit, and studying their interactions, could provide additional information about the nature of fruit decay resistance and $P$. cucurbitae latent infection. These studies are currently being conducted in our laboratory.

\section{ACKNOWLEDGMENTS}

We thank D. Baze, R. Powell, and A. Dillard, biological research technicians at the South Central Agricultural Research Laboratory, USDA-ARS, Lane, OK, for their technical support of this project.

\section{LITERATURE CITED}

1. Abu-Goukh, A. A., Greve, L. C., and Labavitch, J. M. 1983. Purification and partial characterization of "Bartlett" pear fruit polygalacturonase inhibitors. Physiol. Plant Pathol. 23:111-122.

2. Bahkali, A. H. 1995. Production of cellulase, xylanase, and polygalacturonase by Verticillium tricorpus on different substrates. Bioresour. Technol. 51:171-174.

3. Bateman, D. F., and Basham, H. G. 1976. Degradation of plant cell walls and membranes by microbial enzymes. Encycl. Plant Physiol. New Ser. 4:316-355.

4. Bateman, D. F., and Miller, R. L. 1966. Pectic enzymes in tissue degradation. Annu. Rev. Phytopathol. 4:119-146.

5. Beraha, L., and O'Brien, M. J. 1979. Diaporthe melonis sp. nov., a new soft rot of market cantaloupes. Phytopathol. Z. 94:199-207.

6. Biehn, W. L., and Dimond, A. E. 1971. Effect of galactose on polygalacturonase production and pathogenesis by Fusarium oxysporum f. sp. lycopersici. Phytopathology 61:242-243.

7. Brown, R. L., Cleveland, T. E., Cotty, P. J., and Mellon, J. E. 1992. Spread of Aspergillus flavus in cotton bolls, decay of intercarpellary membranes, and production of fungal pectinases. Phytopathology 82: 462-467.

8. Bruton, B. D. 1995. Etiology, epidemiology, and control of muskmelon fruit rots. Pages 48-54 in: Cucurbitaceae '94. G. Lester and J. Dunlap, eds. Gateway Printing, Edinburg, TX.

9. Bruton, B. D. 1996. Phomopsis black rot and purple stem. Pages 52-53 in: Compendium of Cucurbit Diseases. T. A. Zitter, D. L. Hopkins, and C. L. Thomas, eds. The American Phytopathological Society, St. Paul, MN.

10. Bruton, B. D., Conway, W. S., Gross, K. C., and Sams, C. E. 1992. Postharvest decay of muskmelon in relation to pectolytic enzymes of three fungal pathogens. (Abstr.) Phytopathology 82:1146.

11. Bussink, H. J. D., Buxton, F. P., Fraaye, B. A., Graaff, L. H., and de Visser, J. 1992. The polygalacturonases of Aspergillus niger are encoded by a family of diverged genes. Eur. J. Biochem. 208:83-90.

12. Caprari, C., Bergmann, C., Migheli, Q., Salvi, G., Albersheim, P., Darvill, A., Cervone, F., and Lorenzo, G. D. 1993. Fusarium moniliforme secretes four endopolygalacturonases derived from a single gene product. Physiol. Mol. Plant Pathol. 43:453-462.

13. Cervone, F., Lorenzo, G. D., Degra, L., Salvi, G., and Bergami, M. 1987. Purification and characterization of a polygalacturonase-inhibiting protein from Phaseolus vulgaris L. Plant Physiol. 85:631-637.

14. Cleveland, T. E., and Cotty, P. J. 1991. Invasiveness of Aspergillus flavus isolates in wounded cotton bolls is associated with production of a specific fungal polygalacturonase. Phytopathology 81:155-158.

15. Cleveland, T. E., and McCormick, S. P. 1987. Identification of pectinases produced in cotton bolls infected with Aspergillus flavus. Phytopathology 77:1498-1503.

16. Cooper, R. M. 1983. The mechanisms and significance of enzymic degradation of host cell walls by parasites. Pages 101-119 in: Biochemical Plant Pathology. J. A. Callow, ed. John Wiley \& Sons, New York.

17. Cooper, R. M., and Wood, K. S. 1975. Regulation of synthesis of cell wall degrading enzymes by Verticillium albo-atrum and Fusarium oxysporum f. sp. lycopersici. Physiol. Plant Pathol. 5:135-156.

18. Di Pietro, A., and Roncero, M. I. G. 1996. Endopolygalacturonase from Fusarium oxysporum f. sp. lycopersici: Purification, characterization, and production during infection of tomato plants. Phytopathology 86 : 1324-1330.

19. Favaron, F., D’Ovidio, R., Porceddu, E., and Alghisi, P. 1994. Purification and molecular characterization of a soybean polygalacturonase-inhibiting protein. Planta 195:80-87.

20. Giltrap, N. J., and Lewis, D. H. 1982. Catabolite repression of the synthesis of pectin-degrading enzymes by Suilus luteus (L. ex. Fr.) S. F. Gray and Hebelone oculatum Bruchet. New Phytol. 90:485-493.

21. Goodenough, P. W., and Kempton, R. J. 1974. Regulation of the synthesis of an extracellular polygalacturonase by Pyrenochaeta lycopersici when grown in medium with limited carbon sources. Phytopathol. Z. 81: 78-84.

22. Gross, K. C. 1982. A rapid and sensitive spectrophotometric method for assaying polygalacturonase using 2-cyanoacetamide. HortScience 17:933-934.

23. Hobson, G. E. 1962. Determination of polygalacturonase in fruits. Nature 195:804-805.

24. Horton, J. C., and Keen, N. T. 1966. Sugar repression of endopolygalacturonase and cellulase synthesis during pathogenesis by Pyrenochaeta terrestris as a resistance mechanism in onion pink root. Phytopathology 56:908-916.

25. Jarvis, W. R. 1994. Latent infections in the pre- and post-harvest environment. HortScience 29:749-751.

26. Johnston, D. J., Ramanathan, V., and Williamson, B. 1993. A protein from raspberry fruits which inhibits endopolygalacturonases from $\mathrm{Bo}$ - 
trytis cinerea and other micro-organisms. J. Exp. Bot. 44:971-976.

27. Le-Cam, B., Massiot, P., and Rouxel, F. 1994. Cell wall polysaccharidedegrading enzymes produced by isolates of Mycocentrospora acerina differing in aggressiveness on carrot. Physiol. Mol. Plant Pathol. 44:187-198.

28. Lester, G. E., and Dunlap, J. R. 1985. Physiological changes during development and ripening of 'Perlita' muskmelon fruits. Sci. Hortic. 26: 323-331.

29. Maldonado, M. C., Strasser de Saad, A. M., and Callieri, D. 1989. Catabolite repression of the synthesis of inducible polygalacturonase and pectinesterase by Aspergillus niger sp. Curr. Microbiol. 18:303-306.

30. McCollum, T. G., Huber, D. J., and Cantiliffe, D. 1989. Modification of polyuronides and hemicelluloses during muskmelon fruit softening. Physiol. Plant. 76:303-308.

31. Misaghi, I. J. 1982. The role of pathogen-produced cell-wall-degrading enzymes in pathogenesis. Pages 17-34 in: Physiology and Biochemistry of Plant-Pathogen Interactions. I. J. Misaghi, ed. Plenum Press, New York.

32. Ohsawa, T., and Kobyashi, T. 1989. Concave rot of melon fruit caused by two Phomopsis fungi. Ann. Phytopathol. Soc. Jpn. 55:409-419.

33. Patil, S. S., and Dimond, A. E. 1968. Repression of polygalacturonase synthesis in Fusarium oxysporum f. sp. lycopersici by sugars and its effect on symptom reduction in infected tomato plants. Phytopathology 58:676-682.

34. Perez, E., and Tena, M. 1990. Purification and characterization of pectic enzymes from two races of Fusarium oxysporum f. sp. ciceri differing in virulence to chickpea (Cicer arietinum L). Physiol. Mol. Plant Pathol. $37: 107-124$.

35. Ried, J. L., and Collmer, A. 1985. Activity stain for rapid characteriza- tion of pectic enzymes in isoelectric focusing and sodium dodecyl sulfate-polyacrylamide gels. Appl. Environ. Microbiol. 50:615-622.

36. Swinburne, T. R., and Corden, M. E. 1969. A comparison of the polygalacturonases produced in vitro and in vivo by Penicillium expansum Thom. J. Gen. Microbiol. 55:75-87.

37. Tenberge, K. B., Homann, V., Oeser, B., and Tudzynski, P. 1996. Structure and expression of two polygalacturonase genes of Claviceps purpurea oriented in tandem and cytological evidence for pectinolytic enzyme activity during infection of rye. Phytopathology 86:1084-1097.

38. Tobias, R., Conway, W. S., and Sams, S. E. 1993. Polygalacturonase isozymes from Botrytis cinerea grown on apple pectin. Biochem. Mol. Biol. Int. 30:829-837.

39. Tobias, R. B., Conway, W. S., and Sams, S. E. 1995. Polygalacturonase produced in apple tissue decayed by Botrytis cinerea. Biochem. Mol. Biol. Int. 35:813-823.

40. Yao, C., Conway, W. S., and Sams, C. E. 1995. Purification and characterization of a polygalacturonase-inhibiting protein from apple fruit. Phytopathology 85:1373-1377.

41. Yao, C., Conway, W. S., and Sams, C. E. 1996. Purification and characterization of a polygalacturonase produced by Penicillium expansum in apple fruit. Phytopathology 86:1160-1166.

42. Zhang, J. X., Biles, C. L., and Bruton, B. D. 1996. Comparison of a latent and non-latent fungal infection of cantaloupe fruit. (Abstr.) Phytopathology 86:S108.

43. Zhang, J. X., Bruton, B. D., and Biles, C. L. 1996. Polygalacturonase and pectate lyase isozymes produced by Phomopsis cucurbitae. (Abstr.) Phytopathology 86:S71. 